\title{
Localizing IT: Smart Kampung as Banyuwangi Regency's Innovation from Below 2015-2020
}

\author{
Dzunuwanus Ghulam Manar ${ }^{1}$, Laila Kholid Alfirdaus ${ }^{2}$, Teguh Yuwono ${ }^{3}$ \\ \{ghulam@lecturer.undip.ac.id ${ }^{1}$ \} \\ Universitas Diponegoro, Indonesia ${ }^{1,2,3}$
}

\begin{abstract}
Smart city has long been criticized for not accommodative to people in rural areas. This is because, smart city is seen too complex for rural people, who are usually known for their simplicity in life and social organization, as compared to people in urban areas. This paper will address internet technology as a tool of innovation. People in rural areas are also usually known for their unfamiliarity with the advancement of technology through the adoption of Internet-of-Thing in public service. In fact, thing can be different. Adopting the main content of smart city, Banyuwangi regency put emphasis the IT empowerment for community in kampung level which is spread out in the rural areas, instead of in city level. However, by putting emphasis on kampung level, Banyuwangi regency has enabled people in the lowest level of governance to access to information as well as to develop their potential to be widely acknowledged by wider audience including those connected through Internet. As a result, within less than a decade Banyuwangi has succeeded to be a magnet for tourism, trading and investment, which lift up the quality of life of the people as well as quality of the governance itself.
\end{abstract}

Keywords: Information and Technology, Smart Kampung, Innovation from Below

\section{Introduction}

Banyuwangi regency as one of the districts with the largest area in Java island with an area of 5,697 km2 which has one of the classic problems namely access and equalization of public services. The condition of Banyuwangi area that stretches from the coastal area to the mountains with diverse layer contours also adds to the complexity of access. There is even an area that requires a road trip of up to 3 hours to access services in the capital of Banyuwangi regency. This condition can be a double- edged knife, one side obstacle in the implementation of development and on the other as a challenge to carry out an even development process for all citizens. For Banyuwangi's Regent Anas [1], the choice of the second side is a challenge to make a government service accessible to all citizens in a concise, fast, and definitive way.

To solve these challenges certainly requires efforts and strategies that are not easy and there seems to be no right instrument other than using internet-based information technology. Since officially taking office as Regent of Banyuwangi on October 21, 2010, Anas [1] has slowly begun to make changes or innovations in governance, including the management of Smart Kampung in response to access problems and the area. Regent Anas [1] chose smart kampung terminology as the match of Smart City which is commonly used by many city governments in Indonesia. While Banyuwangi with 217 villages/villages prefers Smart Kampung as a marker of information technology adoption strategy for community empowerment and modern public services [2]. 
Smart Kampung is expected to solve the problem of government administration and business easily with situation of Banyuwangi which $87 \%$ of the area is rural. By using policy instruments in the form of Regent Regulation (Perbup) No. 18 of 2016 on Integration of Village/Urban Based Work Program through Smart Kampung Banyuwangi, Smart Kampung policy is officially applicable throughout Banyuwangi region. This paper will identify and describe the adoption of internet- based information technology for community empowerment so that there is a change in society to initiate, innovate, and create an even, concise, fast, and definitive public service.

\section{Methodology}

This paper is developed from the research conducted on September-October 2019 in Banyuwangi. The author conducted interviews with Banyuwangi's regent, top official leaders, business people, and some of community member. In-depth interviews were conducted to get information about the background, process, and benefits of innovation that takes place in Banyuwangi and specifically related to Smart Kampung program.

\section{Results and Discussion}

There is no denying that internet-based information technology is very identic with urban communities. Their adaptive and responsive characteristics to technology allow them to be more familiar with internet technology. Beside this is very different from the characteristics of rural communities. Furthermore, urban areas of infrastructure and technology access are easier to do because of heterogeneous needs and interests. Meanwhile in rural areas infrastructure and access is rather difficult to build or use due to activities that tend to be homogeneous. The digital divide phenomenon related to access to technology in urban (centre) and rural (periphery) is common everywhere [3]. This results in the adoption and acceleration of technology use in urban areas more easily than in rural areas.

The above perspective seems no longer relevant to be expressed by looking at the conditions in Banyuwangi Regency. Regent Anas [1] instead saw technology as a positive incentive for development and public service. Modernization can not only be done individually but can also be done together/communally especially with the intervention of government policy. By using Perbup No. 18 year 2016 slowly carried out the process of adoption of internet-based information technology in development activities in Banyuwangi Regency. Through 7 priorities of innovation programs of village/village government services such as public services, economic empowerment, health services, poverty alleviation, education, cultural arts, human resources improvement and legal information, Smart Kampung program are enacted. In order to realize these priorities each village government is encouraged to create programs and innovations to achieve them [4].

The use of internet-based information technology began in villages in cooperation with PT Telkom Indonesia. Through the Smart Kampung program, the adoption of internet-based information technology will be able to create decent public services, formulate comprehensive and integral work programs and ultimately accommodate all parties to the village/village level. The implementation of the adoption of information technology is carried out through the arrangement of facilities, infrastructure, and human resources [5]. The arrangement of 
facilities is carried out by ensuring the physical form of service in each village /village has the same standards and deserves. Aspects such as the existence of village halls including furniture, sound systems, LCD projectors, information boards, learning facilities for children and supporting facilities of OPD activities should be available and can be used. The infrastructure arrangement ensures the availability of electricity, clean water, sanitation, clean toilets, trash cans, print media, greening, libraries and internet connection. Human resource management is carried out through the recruitment of operators and staff as well as trainings.

In order to support the facilities, infrastructure, and human resources there is a commitment from the regent through the budget allocation of APBD as well as the division of OPD to carry out assistance and commitment of the village head through the allocation of APBDes. Budgeting and financing commitments also technical assistance and guidance are essential as policy instruments for the implementation of smart kampung programs.

The implementation of public services at the village level has been done using internetbased such as for the manufacture of certificate, resident administration documents (e-KTP, $\mathrm{KK}$, etc.), recommendation letter and small micro business license (IUMK). In addition, there is no more delayed service, all fast paced and definite. Even the district government opens a complaints channel if there is an unsatisfactory service to report and immediately be acted upon. Community empowerment through creative economic activities also runs with tourist attractions, festivals, culinary, and shopping spread throughout almost all Banyuwangi area. Cooperation with civil society (associations) and private sector and inviting participation and collaboration from all elements (central government, ministries, institutions, State Owned Enterprises) successfully develops village-based creative economic development centers. The process of embodiment of public services and the development of the creative economy involves the participation of parties through ideas and ideas so that villages and citizen have ideas and initiatives to create economic empowerment programs.

From a series of process of building smart kampung program can be identified success achievement among others from 217 villages that exist, as many as 95 villages or about $44 \%$ have entered the advanced category, have good public services as well as Smart Kampung programs that are already running, as many as 98 villages or $45 \%$ enter the category of development, one stage towards the advanced category and 24 villages or $11 \%$ still less so that it needs more serious assistance (www.timesindonesia.co.id). In addition, there was an increase in the per capita income of Banyuwangi residents from 20.86 million per person in 2010 up to 78.48 million per person in 2018. In terms of economic empowerment and creative economy there is a virtual www.banyuwangi-mall.com storefront that presents Banyuwangi goods and services products including tourist events. It is expected to be a onestop online shop of Banyuwangi. Meanwhile, smart kampung is accommodated through https://smartkampung.id/ that accommodates various public services and profiles of villages virtually. These measures at least provide a positive signal for the results of the Smart Kampung program that is able to integrate several aspects of government administration and business (creative economy) based in rural areas.

\section{Conclusion}

From the above discussion at least can be identified the successful adoption of internetbased information technology in rural areas which is quite successful (approximately 89\% undergoing changes/progress). This dismisses the notion that rural areas are sluggish and un responsive to resource changes, particularly information technology. It turns out that rural 
communities are able to use information technology to make changes in services and empowerment. This is in line with the technological vision created for progress for anyone and anywhere who is able to take advantage of it [6]. Although efforts to realize this took a long journey since 2010 when Regent Anas [1] first took office until the declaration of the perbup policy on Smart Kampung in 2016. This is reinforced by commitment from regents and village leaders, assistance and supervision from the district government as well as collaboration with private sector and civil society. In the end, it was initially considered impossible to slowly do that could turn things around and making benefit.

\section{References}

[1] A. L. Romanoff and A. J. Romanoff, "The Avian Egg. Jhon Wiley and Sons," Inc. New York, 1963.

[2] N. L. Pamungkas, "Penyerahan Agenda Politik Pemerintah: Pengelolaan Kebijakan Smart Kampung Berbasis Society Kabupaten Banyuwangi," J. Transform., vol. 6, no. 1, pp. 48-71, 2020

[3] M. Alshehri and S. Drew, "Implementation of e-government: advantages and challenges," in International Association for Scientific Knowledge (IASK), 2010.

[4] R. W. Sekarsari and T. Winarno, "SMART KAMPUNG SEBAGAI WUJUD KEMAJUAN SISTEM ADMINISTRASI DAN MANAJEMEN DI DESA KETAPANG, KECAMATAN KALIPURO, KABUPATEN BANYUWANGI,” JPSI (Journal Public Sect. Innov., vol. 2, no. 2, pp. 82-87, 2018.

[5] and I. P. T. Setiawan, P. Oktawirani, Pemberdayaan dan Inovasi Tata Kelola Pemerintahan Daerah dan Desa. 2016.

[6] V. Homburg, Understanding e-government: Information systems in public administration. Routledge, 2008. 